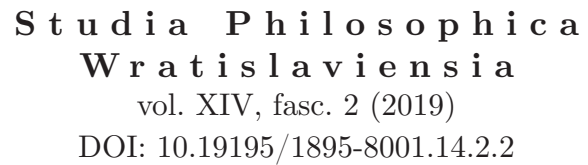

\author{
JAN KRASICKI \\ ORCID: 0000-0003-2700-7715 \\ Uniwersytet Wrocławski
}

\title{
Sacrum i rewolucja. Leszek Kołakowski i inni
}

Rzeczywiste jest to, czego ludzie najbardziej pragną.

Leszek Kołakowski

\section{The sacred and the revolution (Leszek Kołakowski and others)}

\begin{abstract}
The author examines the relationship between the sphere of the sacred and the phenomenon of the revolution. He points to the distinctiveness of Leszek Kołakowski's position as compared to the views articulated by other representatives of the so-called Warsaw school of the history of ideas. He claims that Kołakowski's philosophical programme, which takes into account the sacred and mythical dimension of the socio-political diagnoses, can help us to understand the Russian Revolution of 1917 as well as other revolutionary movements and processes of the 20th century. He demonstrates that the sacred is an inherent aspect of the revolutionary mentality. Also, he argues that the ideologies which turned against religion in the name of the struggle with religious superstitions, in the end became quasi-religious. As a matter of fact, the revolutionary utopia may be perceived as a kind of crypto-religion involving such elements of the mythical thinking as a belief in the cognition of history, an assumption that the latter may be started anew, a belief in the possibility of the secular eschatology, etc.
\end{abstract}

Keywords: revolution, Warsaw School of historians of ideas, revolutionary mentality, French Revolution, myth, sacrum, evil, Enlightenment, religion, eschatology 


\section{Kołakowski i rewolucja. Wobec „,szkoły”}

Leszek Kołakowski znany jest przede wszystkim jako filozof marksistowski oraz marksistowski „rewizjonista”1. Polski filozof nie zajmował się ani rewolucją francuską 1789 roku, jak na przykład Bronisław Baczko², ani rewolucją rosyjską 1917 roku, jak na przykład M. Zdziechowski ${ }^{3}$, ani też rewolucją jako taką, jak na Zachodzie na przykład Hannah Arendt ${ }^{4}$. Namysł nad zjawiskiem rewolucji w jego twórczości pojawi się dopiero w okresie wydarzeń związanych z XX Zjazdem KPZR i polskim „Październikiem”. Kołakowski, nie licząc szkiców z lat siedemdziesiątych O duchu rewolucyjnym (1970), Rewolucja jako piękna choroba (1979) oraz innych przyczynkarskich prac, nie napisał większych rozpraw z tej dziedziny jednak to, co zawarł w tych kilku studiach można odczytać jako próbę stworzenia uniwersalnego paradygmatu rewolucji.

Za kluczową formułę interpretacyjną koncepcji rewolucji Kołakowskiego przyjmijmy jego własne słowa: „Rzeczywiste jest to, czego ludzie najbardziej pragną”. Te pragnienia mają naturę metafizyczną, są dla natury ludzkiej niezbywalne i to one, powiada polski filozof, stanowią klucz w zrozumieniu "ducha rewolucyjnego" . Rewolucję Kołakowski nazywa „piękną chorobą” („piękną”, niemniej „chorobą”), stanem nieuleczalnego dążenia do ustanowienia Nowego Porządku i Nowego Czasu, dążenia występującego w wielu nieraz odległych od siebie w czasie i przestrzeni tradycjach kulturowych i religijnych ${ }^{6}$. W centrum uwagi polskiego filozofa znajdują się jednak nie te ideowe zjawiska, lecz rewolucje będące wykwitem epoki nowoczesnej i filozofii Oświecenia, czyli francuska 1789 roku i rosyjska 1917 roku oraz rewolucje drugiej połowy XX wieku, w tym rewolucja kulturalna w Chinach i Kambodży. Wkład Kołakowskiego, jako jednego z głównych przedstawicieli „Warszawskiej Szkoły Historyków Idei”, w zrozumieniu idei rewolucyjnych wydaje się polegać nie tyle na wzbogaceniu wachlarza analiz, co na czymś zupełnie odmiennym, kwestię przeniósł bowiem na zupełnie inny poziom interpretacyjny, podszedł

\footnotetext{
${ }^{1}$ Por. np. K. Masłoń, Leszek Kołakowski. Filozof rewizjonista, https://www.rp.pl/artykul/335966 -Leszek-Kolakowski-Filozof-rewizjonista.html (dostęp: 11.03.2019).

${ }^{2}$ B. Baczko, Jak wyjść z Terroru: Termidor a Rewolucja, tłum. W. Dłuski, Gdańsk, 2005; B. Baczko, Rewolucja. Władza, nadzieje, rozterki, tłum. W. Dłuski, Gdańsk 2010.

${ }^{3}$ M. Zdziechowski, Chateaubriand i Napoleon, Wilno 1932; M. Zdziechowski, Wpływy rosyjskie na dusze polska, Kraków 1920; M. Zdziechowski, Widmo przyszłości, Wilno 1939; M. Zdziechowski, W obliczu końca, Wilno 1938; oraz J. Krasicki, Eschatologia i mesjanizm. Studium światopogladu Mariana Zdziechowskiego, Wrocław 1994; M. Król, Europa w obliczu końca, Warszawa 2012.

${ }^{4}$ H. Arendt, O rewolucji, tłum. M. Godyń, Kraków 1991.

${ }^{5}$ L. Kołakowski, O duchu rewolucyjnym, [w:] idem, Czy diabeł może być zbawiony $i$ 27 innych kazań?, Londyn 1984.

${ }^{6}$ Jako takie zostało przed wiekami wyrażone na przykład w słynnej IV mesjańskiej zwanej też sybillińską eklodze Wergiliusza, zapowiadającej, zgodnie z przepowiednią Sybilii Kumejskiej, narodzenie z dziewicy dziecka, które zmaże zbrodnie ludzkości, przyniesie światu pokój i zapoczątkuje nową erę. Słowa z tej eklogi (Magnus ab integro saeculorum nascitur ordo — „Na nowo się wielki wieków odradza porządek") cytowane są między innymi przez H. Arendt w jej książce O rewolucji. H. Arendt, O rewolucji, s. 181 .
} 
do zagadnienia rewolucji nie tylko od strony jej przyczyn politycznych i społecznych, lecz także od strony źródeł endogennych antropologicznych, kulturowych, religijnych, metafizycznych, a nawet teologicznych. Obierając taki kierunek, autor Obecności mitu wydaje się zrywać zupełnie z tak czy inaczej pojętym dziedzictwem marksizmu (na przykład Szkoła Frankfurcka) i zbliżać do współczesnych analiz katolickich krytyków nowoczesności i Oświecenia takich jak włoski filozof A. del Noce czy Jan Paweł II (nieprzypadkowo był przez tego ostatniego zapraszany między innymi z Krzysztofem Michalskim oraz Józefem Tischnerem na konferencje w Castel Gandolfo $^{7}$ ). Nie dziwi, że jeden ze znanych amerykańskich intelektualistów nazwał go wręcz „myślicielem katolickim”.

Polski filozof po raz pierwszy tak ściśle łączy rewolucyjne wyobrażenia z religią i eschatologią w niezwykle istotnym wręcz przełomowym dla zrozumienia jego dalszej rewolucji myślowej eseju z końca lat pięćdziesiątych Kapłan $i$ błazen. Rozważania o teologicznym dziedzictwie współczesnego myślenia ${ }^{9}$. Pisze on w nim, że przy swoim świeckim sztafażu,

nietrudno spostrzec że owa eschatologia świecka, a więc wiara w przyszłe zniesienie niezgody między esencją i egzystencją ludzką (to znaczy w deifikację człowieka), zakłada oczywiście, iż „esencja” jest pewną wartością; zakłada, iż realizacja esencji jest pożądana i liczy na mądrość historii która do tej realizacji doprowadzi. Eschatologia świecka ufa historycznemu sądowi ostatecznemu ${ }^{10}$,

co pokazuje zarazem, że idea rewolucyjnej ,radykalnej przemiany” polega na obietnicy zaspokojenia pragnień nie tyle naturalnych, co religijnych.

${ }^{7}$ Por. np. Europa i co z tego wynika (rozmowy w Castel Gandolfo), K. Michalski (red.), Warszawa 1990; O kryzysie (rozmowy w Castel Gandolfo), K. Michalski (red.), Warszawa 1990.

${ }^{8}$ Główne nurty... [marksizmu — J.K.] ukazały się w wielu przekładach i stworzyły okazję do licznych, bardzo interesujących komentarzy. Ostatnie wydanie angielskie pochodzi z minionego roku (2005). Świetny amerykański historyk życia intelektualnego i eseista Tony Judt napisał w tekście opublikowanym właśnie (21 września 2006) w „New York Review of Books” na temat tego wydania: „W sławie tej książki, wśród innych książek Kołakowskiego, tkwi pewna ironia, gdyż jej autor na pewno nie jest przede wszystkim »marksologiem«. Jest filozofem, historykiem filozofii i myślicielem katolickim. Spędził dziesięciolecia na studiowaniu wczesnych nowożytnych chrześcijańskich sekt i herezji i przez ostatnie ćwierćwiecze poświęcił się historii europejskiej religii i filozofii oraz temu, co można określić mianem filozoficzno-teologicznych spekulacji". M. Król, Leszek Wspaniały. https://www.tygodnikpowszechny.pl/leszek-wspanialy-134825 (dostęp: 11.03.2019).

9 „Gdy u schyłku lat siedemdziesiątych o. Andrzej Kłoczowski, późniejszy autor książki Więcej niż mit. Leszka Kołakowskiego spory o religie, prowadził w murach krakowskiego klasztoru Dominikanów zamknięte seminarium na temat Kapłana $i$ błazna, tekst Kołakowskiego krążył wśród uczestników w postaci pliku pożółkłych kartek wyrwanych z numeru miesięcznika „Twórczość” (październik 1959). Kapłan $i$ błazen bowiem, podobnie jak równie sławny wykład Jezus Chrystus — prorok $i$ reformator z 1965 roku, nie trafiły do żadnej z książek Kołakowskiego ogłoszonych przed jego wyjazdem na emigrację. Potem trzeba było czekać aż do roku 1989, kiedy to Zbigniew Mentzel wydał nakładem londyńskiego Pulsu trzy tomy Pism rozproszonych. Owa edycja, bardzo poszukiwana, a równocześnie trudna do zdobycia, doczekała się teraz wznowienia - poprawionego i poszerzonego". Lektor, Wśród książek (omówienie książki: L. Kołakowski, Pochwała niekonsekwencji. Pisma rozproszone sprzed roku 1968, t. 1-3, Z. Mentzel (red.), Londyn 2002).

${ }^{10}$ L. Kołakowski, Kapłan i błazen, [w:] idem, Pochwała niekonsekwencji. Pisma rozproszone sprzed roku 1968, t. 2, Londyn 2002, s. 264. 


\section{Kołakowski ,wieczny rewizjonista”. „Dwoje oczu” Kołakowskiego}

O Kołakowskim mówi się jako o „rewizjoniście”. Jednak jego uwikłanie w marksizm czyni go rewizjonistą nie tylko w obrębie tej doktryny, lecz także w obrębie ideowej „szkoły”, którą współtworzył i z którą jest identyfikowany, czyli „Warszawskiej Szkoły Historii Idei". Odchodząc daleko od jej kanonów, w tym historyzmu, referencyjności, dążenia do historycznej rekonstrukcji zjawisk ideowych na rzecz analizy dającej wyraz własnej aksjologii i egzystencjalnemu zaangażowaniu, daje temu czytelny wyraz. Ale można zapytać, czy ten rewizjonizm na tym się kończy?

Otóż nie, myśl Kołakowskiego jest myślą dramatyczną, myślą w stawaniu się w znaczeniu, jakie słowu „dramat” nadawał J. Tischner (gr. drama — „dzianie się") ${ }^{11}$, myślą „, drodze", ciągle in statu nascendi. To właśnie sprawia, że Kołakowskiego można, parafrazując słowa wieszcza o duchu ,wiecznym rewolucjoniście" (J. Słowacki), poczytywać za rewizjonistę w jeszcze innym znaczeniu tego słowa - za „wiecznego rewizjonistę” i co się wiąże z tym określeniem — poniekąd za właściwego, czyli, „wiecznego rewolucjonistę”. Jeśli zapytać o to z jakich źródeł wypływała ta postawa, trzeba zauważyć, że Kołakowski nawet wówczas kiedy był partyjnym „ortodoksem”, patrzył na sprawy tego świata jakby z podwójnej perspektywy. Widział je, jeśli nawiązać do jego własnej frazy w odniesieniu do Spinozy, niejako „dwoma oczyma"12 i nawet w okresie stalinizmu swoje analizy odnosił do jakiegoś „absolutu”. Przejście to staje się widoczne, jeśli zauważyć, że z jednej strony pomiędzy jego badaniami nad filozofią katolicką, tomizmem i ich zajadłą krytyką lat pięćdziesiątych oraz badaniami nad mitem oraz mistyką chrześcijańską lat sześćdziesiątych rozwiera się ideowa przepaść, z drugiej jednak strony, jeśli wniknąć głębiej w ich ideową treść, okazuje się, że już w pismach z lat pięćdziesiątych cały późniejszy ,religijny” Kołakowski zawarty jest in nuce $e^{13}$. Uważnemu

\footnotetext{
11 Por. J. Tischner, Filozofia dramatu. Wprowadzenie, Kraków 1998.

12 Por. L. Kołakowski, Dwoje oczu Spinozy, [w:] idem, Pochwała niekonsekwencji. Pisma rozproszone sprzed roku 1968, t. 1 .

13 Przypomnijmy w tym miejscu, że na dociekliwość młodego Kołakowskiego w kwestiach religijnych z lat pięćdziesiątych z partyjną czujnością zwrócił uwagę już w 1953 roku Bronisław Baczko, kiedy Kołakowski daleki był jeszcze od swego „rewizjonizmu”. I tak jak czytamy w książce W. Chudoby, 26 marca, w Katedrze Historii Filozofii IKKN (założony przez Adama Schaffa i istniejący do 1954 roku Instytut Kształcenia Kadr Naukowych) na „naukowym zebraniu katedry odbywa się dyskusja nad skryptem Leszka Kołakowskiego Filozofia zachodnio-europejska z XVII wieku (na kontynencie). Recenzentami są Anna Śladkowska i Tadeusz Kroński. W dyskusji, oprócz recenzentów, głos zabierają Henryk Holland i Bronisław Baczko. W opinii Baczki: „podstawowym metodologicznym błędem jest niepotraktowanie rozwoju filozofii XVII walki materializmu z idealizmem. Nie pokazane zostało, w jaki sposób dojrzewał materializm. [...] Błędem dydaktycznym skryptu jest, że pod ilością nagromadzonych szczegółów zginęła główna myśl”. Ponadto jego zdaniem skrypt „cierpi na obsesję religijną, czyli na skrzywienie problematyki, która zajmując się doktrynami religijnymi, nie wykazała walki ideologicznej — wewnątrz religijnej, nie wykazała jak w tym okresie ubrany w szaty religijne rodził się materializm. Skrypt ma charakter obiektywistyczny, bezpartyjny. Stosunek autora do klasyków jest lekceważący". W zakończeniu czytamy: „Tow. Kołakowski ustosunkowując się do uwag zaznacza, że nie wszystkie wydają mu się słuszne"; W. Chudoba, Leszek Kołakowski. Kronika życia i twórczości, s. 98-99. Źródło: Protokół z zebrania Katedry Historii Filozofii z 26 marca 1953, AAN ANS 5/107, s. 85.
} 
czytelnikowi jego pism nie umknie, co zauważyli na przykład B. Baczko i A. Schaff, że już w tamtym „wojującym” okresie jego twórczości zajmował się tematami, jakie — jakby nie do końca — „przystoją” młodemu walczącemu marksiście ${ }^{14}$. Przy wszelkich „sceptycznych” zastrzeżeniach, jakie potem czynił przy analizach koncepcji metafizycznych ${ }^{15}$, już wtedy jego myślenie wyznaczał jakiś bliżej nieokreślony „absolut”, sacrum ${ }^{16}$, Bóg „ukryty”. Dzisiaj mniej lub bardziej zasadnie pisze się o jego „powrocie” do religii ${ }^{17}$, a nawet mówi się o jego specyficznej „wierze” („chcę wierzyć") $)^{18}$.

Ów „wieczny rewizjonista” tak też patrzył na fenomen rewolucji i komunizmu, które, w ich świeckich przebraniach, poczytywał za rodzaj kryptoreligii konstytuowany przez takie elementy myślenia mitycznego i gnostyckiego ${ }^{19}$, jak wiara w możliwość powszechnej odnowy rzeczywistości, w ustanowienie „nowego początku", restytucję czasu in nullo, fundację świeckiej eschatologii, w poznawalność historii itp., wskazujących na obecność w nich duchowych „ostatecznych” ludzkich pragnień. W tym znaczeniu Kołakowski utrzymywał, że

nadzieja Absolutnego Początku, Totalnej Młodości jest, jak się zdaje, stałą i nigdy całkiem nie gasnącą formą życia duchowego ludzi. Nie należy sądzić, by nadzieja ta mogła być kiedykolwiek usunięta z kultury ani nawet, by to było pożądane. Jest ona pragnieniem unieważnienia przeszłości. Rewolucyjne fantazje czasów nowożytnych są historycznym wcieleniem owej nadziei. Jej formą oryginalną są eschatologie religijne, gdzie wiara w Nowy Czas, czyli zbawienie, zakładała oczyszczenie z win, błędów i grzechów czasu dawnego ${ }^{20}$.

14 Jak trafnie zauważa M. Król, ,już wtedy widoczna była pasja towarzysząca mu od wczesnej młodości do dzisiaj, czyli pasja do myśli religijnej, a w gruncie rzeczy do teologii. Świadomość religijna i więź kościelna, w której przedstawione zostały poglądy siedemnastowiecznych heretyków, dotyczy nie tylko tego dość wąskiego tematu, ale natury Kościoła w konfrontacji z naturą wiary. Niektórzy odnajdywali w tym także refleksję na temat wiary i kościoła marksistowskiego, ale myślę, że jest to interpretacja nazbyt banalna" (M. Król, Leszek Wspaniały; https://www.tygodnikpowszechny.pl/leszek-wspanialy-134825 (dostęp: 11.03.019).

${ }^{15}$ L. Kołakowski, Jeśli Boga nie ma... O Bogu, Diable, Grzechu i innych zmartwieniach tak zwanej filozofii religii, tłum. T. Baszniak, M. Panufnik, Kraków 1988. Także J.A. Kłoczowski, Więcej niż mit. Leszka Kołakowskiego spory o religię, Kraków 1994; J.A. Kłoczowski, Sceptyk i mistyk, [w:] Obecność. Leszkowi Kołakowskiemu w 60-lecie urodzin, Londyn 1987.

${ }^{16}$ W. Chudoba pisze wprost o „obronie sacrum” w myśli Kołakowskiego. Por. W. Chudoba, Leszek Kołakowski. Życie z historia w tle, „Res Publica Nowa” 230 [4] (2017), pt. Kołakowski. Raj utracony, (L. Kołakowski. Lost Paradise), https://www.google.com $/$ url?sa=t\&rct=j\&q=\&esrc=s\&source=web\& $\mathrm{cd}=1 \& \mathrm{cad}=$ rja\&uact $=8 \&$ ved $=0$ ahUKEwj51KqFmZ7bAhUO_aQKHXy4BCMQFggnMAA\&url $=$ https\%3A\%2F\%2Fbookstore.dsh.waw.pl\%2Fbookstore\%2F160\&usg=AOvVaw2XWh3p3Jv0mvk97J7xveOe (dostęp: 13.03.2018).

17 Por. B. Wildstein, Kołakowski, czyli z powrotem do religii; https://teologiapolityczna.pl/bronislaw-wildstein-kolakowski-czyli-z-powrotem-do-religii (dostęp: 11.03.2019).

18 Por. A. Bielik-Robson, „Chcę wierzyć”: Kołakowski między mitem a horror metaphysicus, („I Want to Believe": Kotakowski Between Myth and Metaphysical Horror); https://www.google.com/url?sa= $\mathrm{t} \& \mathrm{rct}=\mathrm{j} \& \mathrm{q}=\& \mathrm{esrc}=\mathrm{s} \&$ source $=$ web\&cd $=1 \& \mathrm{cad}=\mathrm{rja} \&$ uact $=8 \& \mathrm{ved}=0$ ahUKEwiLl6KUmJ7bAhVGaFA KHViyBQQQFggnMAA\&url=http $\% 3 \mathrm{~A} \% 2 \mathrm{~F} \% 2$ Fpublica.pl\%2Fteksty $\% 2$ Fbielik-robson-chce-wierzyckolakowski-miedzy-mitem-a-horror-metaphysicus-63512.html\&usg=AOvVaw3u5KQoV_YCvhsG-BuppiUj (dostęp: 13.03.2018).

${ }^{19}$ Por. J. Krasicki, Dwie krytyki gnozy, [w:] J. Krasicki, Przeciw nicości. Eseje, Kraków 2002.

${ }^{20}$ L. Kołakowski, Rewolucja jako piękna choroba, [w:] idem, Cywilizacja na tawie oskarżonych, Warszawa 1990, s. 190. 
Aby jednak lepiej zrozumieć sekrety rewolucyjnej wiary należy poczynić najpierw pewne rozróżnienie.

Z analizy aktu wiary wiemy, że w każdym jej akcie występują zawsze dwa aspekty: rzeczowy, treściowy (uznać „coś”, asercja poznawcza) i relacyjny, egzystencjalny (ufać „komuś”). Oba są ważne, lecz nadzieje religijne opierają się zasadniczo na tym drugim, strona przedmiotowa zostaje w nich odsunięta na plan dalszy. Dlatego nie poddają się one do końca racjonalnej analizie i z tego powodu, pisze polski myśliciel, „nadzieja Nowego Czasu jest oporna na racjonalne argumenty, we właściwej swojej postaci nie jest bowiem »teorią« ani stanowiskiem intelektualnym, ale pasją duchową"21. Oznacza to zarazem, że „eschatologie religijne nie potrzebują żadnej teorii”, że opierają się „na zaufaniu do obietnicy, jaką kiedyś, u początku czasu, ludzie otrzymali: obietnica ta utrzymuje ich wiarę, że przeszłość może być jakby wymazana w moralnym sensie, że łańcuch zła i cierpienia może być radykalnie przerwany" 22 . Nadzieje te, choć próbują występować w formach racjonalnych, choć przedstawiają się jako przeświadczenia oparte na racjonalnych przesłankach („czego — jak powiada Kołakowski — bez złej wiary uczynić niepodobna”), są irracjonalne ze swej natury. Dlatego w imię Nowego Początku „wymazywanie przeszłości" musi mieć w nich z konieczności charakter polityczny, a nie moralny i zwrócony przeciw kulturowemu dziedzictwu przeszłości.

\section{Azjatycki import (z Sorbony do Azji)}

Zadanie to w różnych rewolucjach było realizowane z różną siłą i różnymi sposobami, jednak pasja do zerwania z tradycją nigdzie nie przybrała tak ostatecznego, a zarazem tragicznego wymiaru, jak w „rewolucji kulturalnej” w Chinach i rewolucji „czerwonych Khmerów” w Kambodży. Rosja, nawet po rewolucji bolszewickiej, dzięki swej kulturowej tradycji zdołała się oprzeć całkowitej destrukcji kulturalnej i, jak pisze Kołakowski, „była zdolna wyłonić z siebie nowe energie kulturalne, udowodnić, że nie zerwała więzi ze swoją przeszłością i oparła się wspaniałościom Nowego Czasu"'23. Inaczej rzecz przedstawiała się na gruncie chińskim, albowiem

apokalipsa Chińska była znacznie radykalniejsza, zwłaszcza w epoce tak zwanej rewolucji kulturalnej. Nie tylko dzieło niszczenia przeszłości, odziedziczonej sztuki, filozofii, religii i nauki, niszczenia szkoły i uniwersytetu, prowadzone było znacznie konsekwentniej; o wiele systematyczniej i skuteczniej niszczono także rodzinę jako więź społeczną najbardziej oporną na upaństwowienie. Ideologia rewolucyjna maoizmu wypowiadała też znacznie lepiej i wyraźniej zadania Nowej Epoki: całkowite przekreślenie ciągłości kulturalnej, ulepienie Nowego Człowieka na cywilizacyjnej pustyni. Nie możemy ocenić w tej chwili, do jakiego stopnia praca ta była udana, a w jakim stopniu Chińczycy zdołali przechować, mimo straszliwych zniszczeń, zdolność duchowego odrodzenia; wydaje się jednak, że również tam próba stworzenia Całkowitego Początku nie całkiem się udała ${ }^{24}$.

Jeszcze bardziej krańcową formę realizacji Nowego Początku stanowiła rewolucja w Kambodży (reżim Pol Pota), gdzie dążono do zupełnego zniszczenia prze-

\footnotetext{
21 Ibidem.

22 Ibidem, s. 190-191.

23 Ibidem, s. 192.

24 Ibidem.
} 
szłości. „Przygotowanie Nowej Epoki, czyli niszczenie starego społeczeństwa, nie znało już żadnych ograniczeń. Miasta, szkoły, rodzina, religia, wszystkie formy życia społecznego, wszystkie zasoby cywilizacyjne legły w gruzach"25, albowiem „nowi władcy” słusznie uważali, że dla „ulepienia”, jak pisze polski myśliciel, „Nowego Człowieka” i zbudowania ,podwalin Nowego Czasu”26, należało zerwać całkowicie ze wszystkimi przeszłymi formami kulturalnymi; ,praktycznie oznaczało to, że trzeba wyrżnąć wszystkich piśmiennych, a ocalałą ludność zamknąć jako niewolników w obozie koncentracyjnym”27 i tym sposobem „doskonała Rewolucja - powiada polski filozof — zakłada doskonałą pustynię kulturalną", co w realizacji oznaczałoby regres w filogenezie i powrót do stanu sprzed stadium człowieka rozumnego, a nawet stadium ,przedjęzykowego"28. Rewolucja to unicestwienie przeszłości, a przecież samo jej pojęcie zakłada kultywowanie dorobku przeszłych pokoleń i zbudowane jest na łączności z przeszłością, a nie na zerwaniu z nią, na zachowaniu i pielęgnacji, jak powiada polski filozof, „mitologicznego” pnia cywilizacji, co w istocie równa się zachowaniu człowieczeństwa, które istnieje tylko przez kulturę i żywą więź z tradycją. W Kambodży to unicestwienie kultury i człowieka prawie się udało i była to rewolucja, która, jak Kołakowski stwierdza z przekąsem,

osiągnęła, jak się zdaje, najlepsze wyniki ze wszystkich dotychczasowych. Na jej podstawie historyczne definicje Rewolucji Totalnej, Nowego Czasu i Nowego Człowieka dają się znacznie precyzyjniej sformułować niż kiedykolwiek: ludobójstwo, niewolnictwo, zezwierzęcenie. Apokalipsa prawie się dokonała, i idea rewolucyjna prawie stała się ciałem. Myśl o powrocie Absolutnego Początku, do pięknej Młodości, oderwana od swojej religijnej podstawy, wcieliła się tak, jak najlepiej mogła ${ }^{29}$.

Pisząc te słowa, Kołakowski był jednocześnie doskonale świadom, że ideowe źródła importowanej na azjatycki grunt rewolucyjnej ideologii leżą w starej dobrej Europie, ściślej, znajdują się w filozofii Oświecenia. Dlatego w swym pragnieniu „totalnej przemiany”, jak pisał, komunizm był „przypadkiem takiej konwulsji powstałej z rozpaczliwej potrzeby ostatecznego zbawienia, nowego czasu"30, który „wyrósłszy z tradycji Oświecenia i w warunkach, kiedy tradycyjne wiary opuściły były, w znacznym stopniu, wykształcone elity, przybrał on postać niekonsekwentną religii świeckiej"31. Mając na uwadze ideowe źródła rewolucji i komunizmu, polski filozof doskonale przy tym pamięta, że komunizm chociaż dawno przeniósł już miejsce swojej instalacji i ekspansji poza „stary kontynent”, a role heroicznych rewolucjonistów europejskich XIX stulecia przejęli w XX wieku byli słuchacze paryskiej Sorbony (na przykład na terenie Kambodży Północnej), to jego ideowe korzenie tkwią w tradycji europejskiej, ściślej w filozofii Oświecenia, a ideowe bankructwo komunizmu jest, jak stwierdza, ,zarazem porażką tegoż Oświecenia, które-

25 Ibidem, s. 192-193.

26 Ibidem.

27 Ibidem, s. 193. „Likwidowano” fachowców i intelektualistów, zabijano nawet za sam fakt posiadania okularów lub zbyt delikatnych dłoni. Ogółem zginęło ok. 2-3 milionów ludzi.

${ }^{28}$ L. Kołakowski, Rewolucja jako piękna choroba, s. 193.

${ }^{29}$ Ibidem, s. 193-194.

${ }^{30}$ L. Kołakowski, Komunizm jako formacja kulturalna, [w:] idem, Cywilizacja na ławie oskarżonych, s. 318 .

31 Ibidem. 
go był ostatecznym, najbardziej konsekwentnym, a przez to samoniszczycielskim, wyrazem"32. Zdaniem Kołakowskiego, mimo społecznego i ekonomicznego sztafażu, najgłębsze ideowe korzenie komunizmu pozostają religijne, a nie społeczne i ekonomiczne. Tak pojęte ideologie rewolucyjne stanowią w szczególności „wynaturzony świecki wariant religijnego mesjanizmu" obecnego w buddyzmie, judaizmie i chrześcijaństwie ${ }^{33}$.

\section{Mentalność rewolucyjna. O duchu rewolucyjnym (Luter i Marks)}

Zastanawiajacc się w szkicu $O$ duchu rewolucyjnym nad „mentalnością rewolucyjną" "34, polski filozof za jej cechę dystynktywną przyjmuje myślenie według

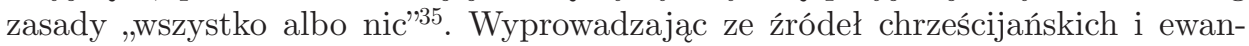
gelicznych żywotność tej postawy ${ }^{36}$, ilustruje ją dwoma tylko z pozoru zupełnie nieprzystawalnymi do siebie postaciami - Lutra i Marksa. W nauce Chrystusa, powiada polski filozof, nie istnieje droga pośrednia, rządzi tu zasada podniesiona przez rewolucyjnych doktrynerów do rangi dogmatu:

zbawienie totalne lub totalne potępienie, myśl o tym, że tylko jedna rzecz jest wartością prawdziwą i że życie musi być tej wartości poddane bez reszty — jest konstytutywną cechą doktryny Chrystusa. Wszystkie moralne są jej konsekwencją, a nadchodzący sąd ostateczny stawia ostatecznego wyboru w sposób naglący i nieodwołalny ${ }^{37}$.

To właśnie ów ewangeliczny radykalizm i totalizm wydaje się najbardziej cechować naukę Lutra, a jego religijna reforma jest dobrym terenem, aby ukazać postawę, którą myśliciel nazywa „mentalnością rewolucyjną”. Opozycja pomiędzy umiarkowaną liczącą się z realiami ziemskiego życia postawą Kościoła w starciu z opartą na teologii łaski Augustyna „lutrową teologią wiary” unaocznia, zdaniem polskiego filozofa, do jakich konsekwencji musi prowadzić postawa, którą nazywa „mentalnością rewolucyjną”. Kościół, jak stwierdza, jako organizm duchowy musiał się liczyć się z tym, że pomiędzy zbawianymi a grzesznikami istnieją ,stany pośrednie"38. Luter odrzucił ten antropologiczny i teologiczny realizm ,pośrednich stanów” i „odkrył ponownie, w swoim mniemaniu, właściwy sens chrześcijaństwa, wyłożony w listach Pawła i w pismach Augustyna a znieprawiony przez Kościół"39.

\footnotetext{
32 Ibidem, s. 318-319.

${ }^{33}$ L. Kołakowski, Rewolucja jako piękna choroba, s. 188.

${ }^{34}$ L. Kołakowski, O duchu rewolucyjnym, s. 217.

35 Ibidem, s. 218.

36 „Idea zbawienia bieżącego życia (»doczesne«) — stwierdza — należy z pewnością do najbardziej istotnych składników chrześcijaństwa, a ściśle — do nauki Chrystusa samego. Nauka Chrystusa jest w całości zorganizowana wokół nadchodzącej apokalipsy; w obliczu rychłego końca świata wszystkie pośrednie drogi są zamknięte: pozostaje wybór między królestwem niebieskim i państwem zła, świat dzieli się na dzieci Boże i odtrąconych, a dzieci Boże to ci, którzy gotowi są oddać wszystko co mają, do ostatniego grosza, za drogocenną perłę Królestwa" (ibidem).

37 Ibidem.

38 Ibidem.

39 Ibidem.
} 
Kryterium zbawienia stała się w jego nauczaniu „wiara”, a nie uczynki, przy czym wiara pojęta nie jako „prawowierne przekonania - ale jako kompletna regeneracja duchowa, sprawiona siłą łaski, a dzięki której wszystkie, nasze uczynki wszystkie sprawy odmieniają natychmiast swój sens; sprawi ona bowiem, że Bóg zechce uznać nas za sprawiedliwych na przekór naszym grzechom" ${ }^{\text {". }}$. Rzecz jasna dla zrozumienia głównej tezy polskiego myśliciela to jednak nie zawiłości teologii Lutra są najważniejsze, lecz ukazanie działania matrycy zwanej przezeń „mentalnością rewolucyjną" i w teologii Lutra, i w teorii Marksa obowiązuje bowiem zasada „wszystko albo nic"; albo absolutne dobro, albo zło, albo „niebo", albo „piekło".

Różnica jest taka, że przy zachowaniu tego samego „dychotomicznego schematu, który wyróżnia pierwotną chrześcijańska naukę o zbawieniu i odkupieniu"41 chrześcijaństwo, uznając naukę o Grzechu Pierworodnym, wymaga ,interwencji odkupicielskiej z zewnątrz" ${ }^{\text {"42 }}$, natomiast "teoria świeckiego zbawienia, czyli rewolucyjna doktryna Marksa”, choć naśladuje dokładnie ten sam schemat, czyni to w „dokładnej opozycji do chrześcijaństwa”, czyli zorganizowana jest wokół „prometejskiej wiary w samowyzwolenie ludzkości" ${ }^{\prime \prime 3}$, ideowy schemat tego układu jest dlań zatem oczywisty, rzecz polega jedynie na wypełnieniu go odmiennie ideową treścią.

Warto przy tym zauważyć, że mesjańskie i prometejskie aspiracje nauki Marksa myśliciel traktuje nie tylko jako imitacje teologii doktrynalnej, lecz także jako świecką soteriologię opartą na teorii dialektyki i alienacji, zwłaszcza dialektyki i teorii alienacji Hegla z jej kluczową kategorią negatywności, wyobcowania i zniesienia przeciwieństw w wyższej ideowej syntezie ${ }^{44}$. W tym też znaczeniu „cała teoria alienacji — jak czytamy — oparta jest na owej dialektyce negatywności, która całej minionej historii nadaje sens przez relatywizację do przyszłego królestwa wolności” ${ }^{\prime 5}$, co, w interpretacji Kołakowskiego, oznacza że, zgodnie z artykułami rewolucyjnej wiary, a „wbrew Heglowi”46, oczekiwane „ostateczne wyzwolenie” nie przyjdzie i przyjść nie może samoczynnie logiką praw rozwoju ducha absolutnego, idei absolutnej czy innej odgórnej mocy, lecz musi być spełnione poprzez czynną i świadomą ingerencję człowieka w bieg historii, dlatego dopiero gdy „ujarzmienie człowieka przez wyobcowane siły osiąga maksimum natężenia, spełnione są warunki ostatecznej rewolucji, w której ludzkość raz na zawsze wyzwoli się z panowania sił obcych" $"$. Działanie to powinno być zatem zamierzone i celowe, wyznaczone uprzednim rozpoznaniem właściwego momentu dziejowego, owego historycznego hic et nunc i jedynie tym sposobem, jak stwierdza polski myśliciel, dialektyka i teoria alienacji przygotowuja grunt pod „ostateczne wyzwolenie" proletariatu, a zło wydarzające się w historii, włączone w rewolucyjny plan dziejów tą drogą

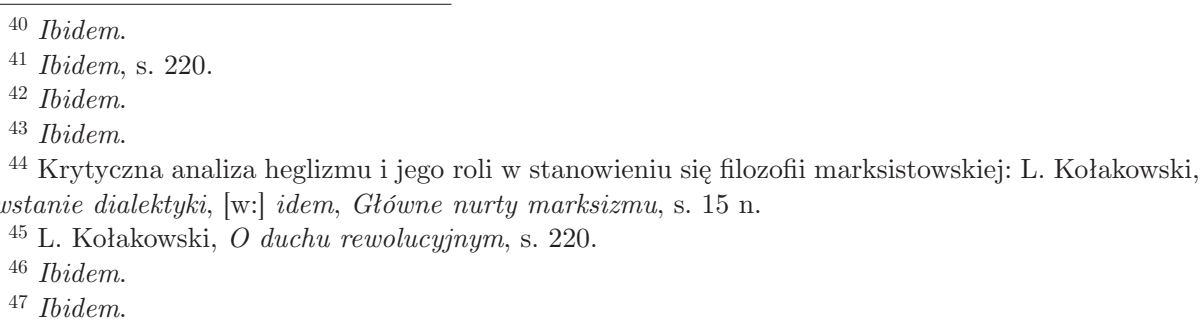


zyskuje dziejowe uzasadnienie. Rewolucja, tak samo jak poprzedzające ją dziejowe zło, w ocenie jej promotorów stanowi dziejową Nemezis, albowiem ,zstąpienie do piekieł poprzedza bezpośrednio wielkie zmartwychwstanie"48, tym sposobem po

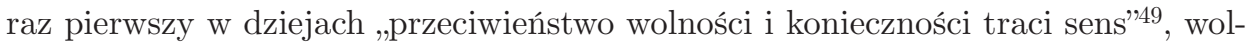
ność i konieczność w walce o „ostateczne wyzwolenie” zbiegają się z sobą, stając się koniecznością dziejową. Człowiek osiąga wyzwolenie od mniemanych niezależnych od ludzkiej świadomości potęg mających nad nim władzę, następuje „powrót człowieka do samego siebie"50 oraz zniesienie ,ideału".

Zdaniem polskiego myśliciela konieczność rewolucji jako położenia ostatecznego kresu dziejowemu złu w rewolucyjnej ideologii zdaje się wynikać nie tylko z logiki dziejów, lecz także z natury kapitalizmu, przeciw któremu występuje, ustrojowi zdolnemu jedynie do działań reformistycznych, a nigdy rewolucyjnych, czyli zmieniających samą jego istotę i leżących całkowicie poza jego możliwościami. Z tego powodu mogą one być urzeczywistnione jedynie drogą rewolucyjnej praxis. Jak pokazuje polski filozof, dla rewolucyjnych doktrynerów było czymś oczywistym, że celów rewolucji nie sposób zrealizować jedynie „częściowo” (takie propozycje wnosił na przykład ,socjalizm reformistyczny”51), można je zrealizować totalnie albo wcale; ,kapitalizm nie może być naprawiony, może być tylko zniszczony" ${ }^{\prime 2}$. Sprzeczności kapitalistycznego systemu nie mogą być wewnątrz zniesione: ich „działanie może być częściowo i chwilowo osłabiane w skutkach, lecz nie unicestwione; rosnąca polaryzacja klasowa i rosnący wyzysk są ich nieuchronnym skutkiem"53. Dlatego, pisze Kołakowski, ,jedyny rzeczywisty sens walki ekonomicznej i akcji reformatorskiej polega na tym, że przygotowują one klasę robotniczą do ostatecznego boju; walka o reformy musi być tędy podporządkowana celowi politycznemu - rewolucji, która z kolei jest narzędziem ekonomicznego wyzwolenia"54. Zgodnie z tą żelazną argumentacją, to nie „miękkie” formy marksizmu na przykład Szkoły Frankfurckiej prowadzą do osiągnięcia wyzwolicielskiego celu, lecz rewolucja totalna.

Jak widać Kołakowski w doktrynie marksistowskiej dostrzega, rzecz jasna poza czynnikami społeczno-ekonomicznymi, przede wszystkim przemożne władanie irracjonalnych sił nieuświadamianych przez jej promotorów. Tym samym panowanie „ducha rewolucyjnego" 55 , a zarazem zasada ,wszystko lub nic" wyznawana przez

\footnotetext{
48 Ibidem.

49 Ibidem.

50 Ibidem.

51 Ibidem, s. 222.

52 Ibidem, s. 221. Analogiczne tezy co do „niereformowalnej” natury kapitalizmu: S. Žižek, Posłowie: Wybór Lenina, [w:] idem, Rewolucja u bram. Pisma wybrane z roku 1917 W.I. Lenin, tłum. S. Kurtyka, Kraków 2006.

${ }^{53}$ L. Kołakowski, O duchu rewolucyjnym, s. 220.

54 Ibidem.

55 „Ta właśnie myśl, iż sens wszelkich reform i wszelkiej walki ekonomicznej zrelatywizowany do celu ostatecznego należy do rdzenia marksistowskiej i z tego punktu widzenia opozycja między reformistycznym duchem II Międzynarodówki a marksizmem była istotnie fundamentalna, a jeśli Engels, w ostatnim nim okresie życia, przypisywał reformatorskiej akcji wartość samoistna (nie przekreślając zresztą idei rewolucji), to również on sprzeniewierzy się duchowi Marksa w istotnym punkcie. W tym
} 
Lutra i Marksa zbiegaja się dlań w jednym punkcie: „zbawienie totalne lub totalna niewola"56. Zbawienie, które idzie z tak czy inaczej pojętej „wiary"; niezależnie od tego czy będzie to paulińska pistis, czy Marksowska wiara w prometejską i mesjańską sakrę proletariatu; albo potępienie, które idzie z jej braku.

I Luter, i Marks, konkluduje Kołakowski, wybierając postawe „wszystko albo nic” i odrzucając „stany pośrednie”, jednak przegrali. Luter przegrał ze swoim „duchem rewolucyjnym", uznał bowiem świat i człowieka za tak doszczętnie zepsuty, że naprawić go niepodobna i wybrał ich totalną regenerację, a że w świecie ostatecznych rozwiązań nie ma, skazał swoją reformę na instytucjonalną klęskę. Dlatego, jak powiada polski filozof, to nie on, lecz „konserwatywny Kościół rzymski”, który „był bliższy realiom ziemskiego życia”, jak na razie, po dziś dzień rządzi owczarnią Chrystusową. Podobnie przegrał Marks ze swoją doktryną totalnej regeneracji, która (niezależnie od dziejowych bied, jakie przyniosła z sobą jej realizacja), miała okazać się totalnym wyzwoleniem, ,skokiem z królestwa konieczności do królestwa wolności" ${ }^{57}$ a okazała się, jak wyraził się autor Obecności mitu, „największa fantazją naszych czasów".

\section{O istocie rewolucji}

W szkicu z lat siedemdziesiątych Rewolucja jako piękna choroba Kołakowski podjął rozważania już nie tyle nad istotą „ducha rewolucyjnego”, co nad samą istotą rewolucji ${ }^{58}$. Jak powiada polski filozof wydarzenie, które miało miejsce 14 lipca 1789 roku we Francji, stworzyło „uniwersalny paradygmat”, który stanowi „osobną klasę doktryn czy ideologii”, a ,ich szczególną cechą jest antycypacja nie po prostu lepszego ładu społecznego, ale pewnego stanu ostatecznego, który raz na zawsze usunie z życia ludzkiego źródła konfliktów, niepokojów, walk i cierpień"59. Osiągniecie zaś praktyczne tego „antycypowanego” stanu, w którym wszystkie dotąd

sensie - powiada polski filozof — dominuje istotnie w marksistowskiej doktrynie: zbawienie jest totalne i ostateczne albo żadne; nie ma wyjść pośrednich; mnożenie reform nie może rewolucji ani zastąpić, ani jej »częściowo « zrealizować, a rewolucja nie powstaje przez ich dodawanie. Kapitalizm nie może być naprawiony, może być tylko zniszczony. W perspektywie przyszłości tylko jedno się liczy — wyzwolenie totalne i ostateczne i tylko ze względu na ten cel akcje częściowe, wewnątrz kapitalistycznego systemu, mogą mieć sens. Wyzwolenie jest niestopniowalne i niepodzielne, rewolucja przyszłości może być tylko globalna tj. musi obejmować wszystkie dziedziny życia społecznego i wszystkie je radykalnie przekształcać- albowiem w historii dotychczasowej wszystko co można nazwać postępem w technologii i kulturze, obracało się ostatecznie przeciwko człowiekowi". Ibidem, s. 220-221.

56 Ibidem, s. 221.

${ }^{57}$ Por. A. Walicki, Marksizm i skok do królestwa wolności. Dzieje komunistycznej utopii, Warszawa 1996.

58 Pisał: „Nazywamy rewolucją ruch masowy, który przez zastosowanie przemocy przerywa ciągłość istniejącego systemu legitymizacji władzy. Udział znacznych mas ludzkich odróżnia rewolucje od zamachów stanu, akt przerwania ciągłości w systemie legitymizacji odróżnia je od legalnych przemian konstytucyjnych, jeśli odbywają się wewnątrz zastanego mechanizmu władzy i bez naruszania jej prawomocności. Zamach stanu może być w wynikiem lub składnikiem procesu rewolucyjnego, lecz może, oczywiście, dokonać się bez rewolucji, jak też najczęściej bywa”. L. Kołakowski, Rewolucja jako piękna choroba, s. 178.

59 Ibidem. 
rzeczywiste lub na „pozór nierozwiązywalne sprawy w życiu społecznym, w konfliktach międzynarodowych, klasowych czy innych"60 zyskują rozwiązanie ostateczne — jest ono jedno i to samo „dla wszystkich spraw”61 i ,nazywa się Rewolucją"62.

Mówiąc inaczej, idea rewolucji to idea „totalnej przemiany”, wszedłszy na jej drogę, rewolucja wstępuje jednak nieodwołalnie na drogę religijną, zwrócona przeciw religii, pozostając w kręgu quasi-religijnych i mitycznych wyobrażeń, sama $\mathrm{w}$ swej ideologii i postawach religijną się staje. Występując przeciw mitycznym treściom sama kreuje nowy mit, mit rewolucyjny. Jak dowodzi polski myśliciel, aby uzasadnić swoje racje, ideologia rewolucyjna musi sięgać do „mitologicznego”, a nie „technologicznego", instrumentalnego „pnia” cywilizacji ${ }^{63}$, co potwierdza zarazem tezę o niemożliwości totalnej jej „demitologizacji”, tezę, że tak czy inaczej pojęta, także na sposób „rewolucyjny”, nie istnieje żadna „kultura doszczętnie wypłukana z mitologicznych składników" ${ }^{\prime \prime 4}$.

Dla uzasadnienia tej tezy niezbędne wydaje się odwołanie Kołakowskiego do teorii „obecności mitu”65. Zdaniem polskiego filozofa „mity”, w tym rewolucyjne, stanowią odrębną od sfery empirycznej i racjonalnej rzeczywistość bytową i rządzą się własną i odrębną logiką, „mity są nieprzetłumaczalne na język niemitologiczny i na próżno próbujemy interpretować je racjonalnie" ${ }^{\prime 66}$. Mitu nie da się zredukować do ,abstrakcyjnej”, racjonalnej doktryny i tak jak ,nie ma sposobu, w jaki chrześcijaństwo mogłoby się zdemitologizować”67, tak „nie ma sposobu”, w jaki można by dokonać tego w obrębie wyobrażeń rewolucyjnych. Słowem, aby strawestować słowa Kołakowskiego na temat możliwości demityzacji chrześcijaństwa albo przyjmujemy rewolucję i komunizm z całym dobytkiem ich „mitologicznego” inwentarza, z ich „teologią”, „dogmatami” i tym podobne, albo nie przyjmujemy ich wcale ${ }^{68}$.

Zauważmy przy tym, że polski filozof wyraźnie nawiązuje tutaj do religiologicznych koncepcji numinosum R. Otto ${ }^{69}$ oraz sacrum M. Eliadego ${ }^{70}$, majacych w ich ujęciach charakter religijnego a priori i niepotrzebujących innych uzasadnień poza nimi samymi. Wedle polskiego filozofa, podążającego tu za M. Eliadem, sacrum po prostu jest sacrum, choć w historii się przejawia, wbrew Heglowi i marksistowskiej dialektyce, i nie podlega historycznemu i dialektycznemu ,zniesieniu” (Aufhebung). Sacrum jest ahistoryczne, a nie historyczne.

\footnotetext{
${ }^{60}$ Ibidem, s. 179 .

61 Ibidem.

62 Ibidem.

63 Np. M. Flis, Leszek Kołakowski - teoretyk kultury europejskiej, Kraków 1992.

${ }^{64}$ L. Kołakowski, Obecność mitu, Wrocław 1994, s. 123.

65 Por. ibidem.

${ }^{66}$ L. Kołakowski, Iluzje demitologizacji, [w:] Cywilizacja na ławie oskarżonych, s. 228.

67 Ibidem, s. 233.

${ }^{68}$ Polemizując z tezami ,demitologizacji” R. Bultmanna, stwierdzi: „Nie da się uciec przed alternatywą: albo akceptacja »mitologiczna « chrześcijaństwa, albo racjonalizm scjentystyczny, który całkowicie obchodzi się bez Boga". L. Kołakowski, Jezus ośmieszony, Esej apologetyczny i sceptyczny, tłum. D. Zańko, Kraków 2014, s. 96.

${ }^{69}$ R. Otto, Świętość. Elementy racjonale i irracjonalne w pojęciu bóstwa, tłum. B. Kupis, Wrocław

${ }^{70}$ M.in. M. Eliade, Sacrum $i$ profanum. O istocie religijności, tłum. R. Reszke, Warszawa 1996.
} 1993. 
Wedle Kołakowskiego związek pomiędzy rewolucją i sacrum jest organiczny i endogenny, przy czym pierwotność sacrum wobec rewolucji oznacza zarazem, że niemożliwością jest zdemitologizowanie i zdesakralizowanie rewolucji, która mimo swego świeckiego sztafażu, zawsze wyraża się poprzez quasi-religijne ryty i symbole. Co więcej, rewolucja fenomenalizuje sacrum i zachowania sakralne jak żadne inne wydarzenie społeczne i polityczne. W tym znaczeniu Kołakowski mógłby powiedzieć, że wszystkie rewolucje są ze swej istoty sakralne, a świecka rewolucja to contradicio in adiecto.

To właśnie, jak zauważa A. Walicki ${ }^{71}$, czyli nie tylko historyczne, ale i „ejdetyczne", fenomenologiczne podejście do zjawisk społecznych umożliwiło Kołakowskiemu wykroczenie poza ideowe ramy „szkoły”, za której współtwórcę się go uważa, „szkoły”, której ideowe zasady współtworzył, a zarazem nieustannie je łamał i przekraczał. Ujęcie sacrum Kołakowskiego — stwierdza Walicki — jest fenomenologiczne i polski filozof ,zgadza się Rudolfem Otto, Maxem Schelerem i innymi fenomenologami, że wiara religijna, doświadczenie sacrum należy do kategorii nieredukowalnych zjawisk pierwotnych, ale twierdzi, że jej różne konkretne przejawy mogą, i powinny być wyjaśniane historycznie"72.

Ponieważ „sacrum jest”, w istocie nic nie można zrobić, aby się go pozbyć. $S a$ crum to zarazem, jak pokazywał Otto, numinosum, czyli przemoc i krwawe kulty (na przykład kult bogi Kali w Indiach, przemoc w Starym Testamencie) ${ }^{73}$. W ujęciu Otta na sacrum jako numinosum składają się zawsze i nierozłącznie elementy „racjonalne” i ,irracjonalne”. Numinosum ma charakter a priori i nie sposób go zanegować, jego „ciemnej”, irracjonalnej, misteryjnej strony. Dlatego rewolucyjna praxis jest manifestacją nowego zła (na przykład nieznane dotąd formy i sposoby terroru), jak i kontynuacją starego, odwiecznego zła jako misterium iniquitatis, zła, którego natury wprawdzie jej ideolodzy nie byli w stanie rozpoznać, niemniej przerażającego w swej sile i skuteczności. Zła biorącego początek w mitach o Upadku, w mitycznej historii zła. Inicjując nowe zło, rewolucja zarazem stawała się uczestnikiem, jak powiedziałby P. Ricoeur ${ }^{74}$, starego „nieludzkiego” zła symbolizowanego przez Węża z Raju.

Wedle polskiego myśliciela, który bliski był tutaj diagnozom M. Zdziechowskiego $^{75}$, dzieje rewolucji we Francji, jak w Rosji, są tego doskonałym potwierdzeniem. Zło — stwierdzał Zdziechowski — nie tylko, że nie zostało w nich wyeliminowane, lecz spotęgowane do postaci monstrualnej, co zarazem suponuje, iż działo się ono

71 A. Walicki, Leszek Kołakowski i warszawka szkoła historii idei, „Aletheia” 1, 1987. s. 128.

72 Ibidem, s. 129.

${ }^{73}$ R. Otto, Świętość, passim.

74 Jak pisze francuski hermeneuta: „wypowiedzenie się o złu jako ludzkim wywołuje wyznanie drugiego stopnia, mówiące o złu jako nieludzkim”, w którym: „Wąż to coś więcej niż transcendencja grzechu w ogóle wobec poszczególnych grzechów, coś więcej niż nie ustanowiona strona tego, co ustanawiane, coś więcej niż korzeń bezwzględnego zła, to Inny, to Przeciwnik, biegun przeciwuczestnictwa, przeciw-podobieństwa, o którym nic się nie da więcej powiedzieć poza tym, że zły postępek w toku samoustanowienia się daje uwieść się przeciw-ustanowieniu emanującemu z ogniska nieprawości, którego figura jest Zły, Diabeł" (P. Ricoeur, Symbolika zła, tłum. S. Cichowicz, M. Ochab, Warszawa 1986, s. 296-297).

${ }^{75}$ Por. J. Krasicki, Eschatologia i mesjanizm. Studium światopoglądu Mariana Zdziechowskiego. 
wbrew na przykład oświeceniowemu ,mistycyzmowi Rozumu” i roszczeniom do naukowości w rewolucji bolszewickiej, z przesłanek metafizycznych i irracjonalnych, a nie racjonalnych ${ }^{76}$. Zdziechowski nie mógł sobie wyjaśnić przyczyn rewolucji bolszewickiej w 1917 roku w Rosji inaczej niż jako „wtargnięcie” sił pozaświatowego metafizycznego zła w rzeczywistość naszego świata. Analogicznie, czyli w metafizycznym, a nie jedynie społeczno-politycznym kluczu, nie tylko w wymiarze historiozoficznym i cywilizacyjnym, lecz przede wszystkim metafizycznym, odczytywał rewolucję 1789 roku we Francji.

Wiara, że zło można raz na zawsze usunąć z oblicza Ziemi pojawiła się dopiero w Oświeceniu, a to, co wcześniej odrzucono jako teologiczną herezję (pelagianizm), podniesiono w filozofii Oświecenia i ideologii rewolucji francuskiej do rangi naczelnego artykułu rewolucyjnej wiary, wręcz dogmatu ${ }^{77}$. Tymczasem, jak pisze M. Król, ,zło oczywiście nie zniknęło dlatego, że jego źródło, czyli wiarę, za przesąd uznał Diderot, ale pojawiła się potężna i do dzisiaj nieporzucona nadzieja na to, że można zbudować świat bez obecności zła"78. Owszem, „nadzieja ta istniała i wcześniej, ale była wyrażana przez niewielkie grupy religijne, które słusznie tępiono"79.

Dlatego, podążając za rozumowaniem Kołakowskiego, na pytanie B. Baczki o to ,jak wyjść z Terroru" ${ }^{10} \mathrm{w}$ obrębie logiki rewolucji odpowiedź może być tylko jedna: zwiększyć terror ${ }^{81}$. W okresie aktywnego zaangażowania polskiego filozofa po stronie walki „o Polską Republikę Rad"82, usprawiedliwiającego terror i prze-

76 Ibidem, s. 38 n.

77 Por. J.C. Duarte, Problem zła w filozofii współczesnej, tłum. L. Balter, „Communio. Międzynarodowy Przegląd Teologiczny” 3 (1990). „Właśnie przeciwko chrześcijaństwu jako religii zbawczej zwracają się ataki ludzi Oświecenia i wobec tego uderzają oni bezpośrednio w naukę o grzechu pierworodnym. Człowiek Oświecenia wierzy, że rozum ma moc udoskonalenia człowieka i dlatego nie może dopuścić do twierdzenia, (jakoby) istnieje zbawienie pochodzące z zewnątrz, od Boga, i że człowiek w ogóle potrzebuje zbawienia, a nie jest po prostu sam z siebie zdolny do poprawy" (P. Henrici, Filozofowie a Grzech pierworodny, tłum. A. Parzonko, „Communio. Międzynarodowy Przegląd Teologiczny" 4, 1991).

78 M. Król, Europa w obliczu końca, s. 13.

79 Ibidem.

${ }^{80}$ Por. B. Baczko, Jak wyjść z Terroru.

81 „W czasach stalinowskich Kołakowski ostro zwalczał tzw. filozofię burżuazyjną. Szczególnie niewybrednie atakował Kościół katolicki. Instytucję tę traktował jako ostoję ciemnoty i zabobonu, pisał też o »kolaboracji Watykanu z Hitlerem«. Zapewne z tego powodu, kreśląc ostatnio biogram Kołakowskiego w katolickim » Tygodniku Powszechnym« (Leszek wspaniały, 1.10.2006 roku), Marcin Król rozpoczął swą opowieść dopiero od 1962 roku. Sam bohater szkicu zachowuje w tej kwestii więcej intelektualnej rzetelności. W $»$ Die Zeit« w latach siedemdziesiątych Kołakowski stwierdził, że w czasach stalinowskich jego stanowisko filozoficzne akceptowało terror i przemoc jako »obronę wartości uniwersalnych«. Dopiero antysemickie i szowinistyczne hasła z 1949 roku miały spowodować pierwsze wątpliwości. »Potrzeba było [...] czasu i doświadczenia — mówił po latach filozof — by dostrzec prostą prawdę, że przemoc rodzi przemoc, a nie służy wolności; że terror jest terrorem, a nie środkiem wymierzania sprawiedliwości — krótko mówiąc, że środki determinują sens i istotę celu «" (P. Gontarczyk: Kołakowski poza zasiegiem SB; http://www.teologiapolityczna.pl/piotr-gontarczyk-kolakowski-poza-zasiegiem-sb (dostęp: 11.03.2019).

82 „Początkowo nic nie zapowiadało, że Leszek Kołakowski stanie się obiektem intensywnego rozpracowywania SB. Z komunistami związał się tuż po wojnie, w czasie studiów filozoficznych na Uniwersytecie Łódzkim. Według jednej z notatek SB z lat sześćdziesiątych miał kiedyś wspominać: »Myśmy chodzili i nosili czerwone gwiazdki z sierpem i młotem, śpiewaliśmy piosenki ze słowami Brunona 
moc jako dziejową konieczność, było to dlań oczywiste. Dokonując obrachunku z własną polityczną przeszłością, po latach otwarcie przyznawał on, że „w czasach stalinowskich jego stanowisko filozoficzne akceptowało terror i przemoc jako »obronę wartości uniwersalnych «"83.

\section{Rewolucja i gilotyna. Wobec zła}

Jeśli w tym miejscu nawiązać do teorii mimetyzmu sakralnego R. Girarda w logice rewolucji, czyli zarazem w logice terroru, zarówno Robespierre, Saint-Just, jak i Dzierżyński byli niejako z odgórnej instancji predysponowani do zachowań mimetycznych i sakralnych, niejako przymuszeni byli odpowiadać na mniemane zagrożenia postępującą centralizacją władzy i spotęgowaniem „terroru" ${ }^{\prime \prime}$ nie dlatego, że byli aż tak okrutni (owszem, tacy także byli), ale dlatego, że innej alternatywy w logice zachowań mimetycznych nie ma. Jak powiada Girard, „przemoc i sacrum są nierozłączne" ${ }^{85}$. Dodajmy, że ideowy grunt tego „despotyzmu wolności”, spośród innych luminarzy Oświecenia, przygotował między innymi J.J. Rousseau, który w Umowie społecznej pisał wprost o, ,zmuszaniu do wolności" ${ }^{\prime \prime 6}$.

Jeśli teraz z kolei nawiązać do diagnoz F. Dostojewskiego, wydaje się, że ów mimetyczny sekret rewolucji najprecyzyjniej wyraził chyba Szygalow z powieści Biesy, który istotę przyszłego ustroju ludzkości zawarł w słowach: „Zaczynam od nieograniczonej wolności, lecz kończę na nieograniczonym despotyzmie" ${ }^{87}$. Istotniejsze z punktu logiki naszych wywodów wydaje się jednak zdanie, które po nim następuje: „Muszę jednak zaznaczyć, że innego rozstrzygnięcia zagadnień społecz-

Jasieńskiego, która się kończyła 'o Polską Republikę Rad'. Nosiliśmy nagany w kieszeniach, przyjaźniliśmy się z bezpieką, takich nas było niewielu na uniwersytecie. Myśmy w zasadzie nienawidzili tej nacjonalistycznej frazeologii Gomułkowskiej. Tej, co głosiła — demokracja, naród, Maria Konopnicka, Kościuszko. To wszystko bzdura. My jesteśmy komunistami i chcemy komunizmu. To, że się wyrzuciło [w 1948 roku] Gomułkę, było dla nas bardzo przyjemne«" (P. Gontarczyk, Kołakowski poza zasiegiem $S B)$.

${ }^{83}$ P. Gontarczyk, Kołakowski poza zasiegiem $S B$.

84 J.L. Talmon, Źródła demokracji totalitarnej, tłum. A. Ehrlich, Kraków 2015, s. 105 n.

${ }^{85}$ R. Girard, Sacrum i przemoc, tłum. M. i J. Plecińscy, Poznań 1994, s. 120. Także J. Stecko, Czy potrzebne jest nam sacrum? Diagnoza kultury w ujęciu Leszka Kołakowskiego, http://doi.prz.edu. $\mathrm{pl} / \mathrm{pl} / \mathrm{pdf} / \mathrm{einh} / 27$ (dostęp: 11.03.2019); A Chodubski, O mimetycznym objaśnianiu rzeczywistości politycznej, http://cejsh.icm.edu.pl/cejsh/element/bwmeta1.element.desklight-fbb2784f-6fa1-4c07-ad13-36c7a81b4c71 (dostęp: 11.03.2019).

86 „Aby więc umowa społeczna nie była pustą formułą, zawiera ona zobowiązanie domyślne, które jedynie może nadać moc obowiązkom innym, jeżeli odmówi posłuszeństwa woli powszechnej, będzie do tego zmuszony przez całe ciało, co nie oznacza niczego innego jak tylko to, że będzie zmuszony do wolności. Bo ten właśnie warunek, oddając każdego obywatela ojczyźnie, gwarantuje mu niezależność osobistą warunek, który stanowi sztukę działania maszyny politycznej i który jedynie nadaje zobowiązaniem społecznym charakter prawowity, bez czego byłyby one niedorzeczne, tyraniczne i narażone na ogromne nadużycia". J.J. Rousseau, Umowa społeczna, tłum. A. Peretiatkowicz, Kęty 2009, s. 22. Także J. Szacki, Kontrrewolucyjne paradoksy, Warszawa 1965; J. Garewicz, Kant i gilotyna, [w:] Dziedzictwo Kanta, Warszawa 1976; W. Gromiec, Kant a Rewolucja Francuska, „Archiwum Historii Filozofii i Myśli Społecznej" 5, 1979; A. Gniazdowski, Filozofia i gilotyna. Tradycjonalizm Josepha de Maistre'a jako hermeneutyka polityczna, Warszawa 1996.

${ }^{87}$ F. Dostojewski, Biesy, tłum. T. Zagórski, Warszawa 1977, s. 393. 
nych nie ma i być nie może [wyróżnienie - J.K.]". Dlaczego? Odpowiedź Szygalowa „propagatora stu milionów głów"88 do ścięcia w imię przyszłego szczęścia ludzkości, odrzucającego „papierkowe tworzenie przepisów dla przyszłej ludzkości”, „gadaninę”, „humanitarne sposoby” i „liberalne krasomówstwo" 89 może być tylko jedna i jako taka wynika z logiki rewolucji, czyli musimy tak uczynić, albowiem „Inaczej wszyscy zginiemy”"90. Gilotyna jest lekarstwem na wszystko, tylko nie na samą rewolucję.

Rodzi się tutaj zarazem centralne dla antropologii Kołakowskiego pytanie o postawę człowieka, a ściślej chrześcijanina, wobec zła. Odpowiedź polskiego filozofa w swej istocie jest taka sama, jakiej udzielił Jan Paweł II, nauczając o „złu wewnętrznym”, intrinsece malum, który mówiąc o światowych ,strukturach zła”, jednocześnie podkreślał, że winny zła jest zawsze konkretny człowiek, że zło jest złem konkretnego człowieka i ,tkwi w czynie"91 (w znaczeniu „czynu ludzkiego” — actus humanus a nie actus hominis). Jak uczył Jan Paweł II, istnieją czyny, których nie wolno popełniać nigdy i w żadnych okolicznościach. Dla Kołakowskiego postawa taka nie oznacza bynajmniej bierności chrześcijanina wobec zła, oznacza jedynie, że nie da się wprost zwalczyć zła przez likwidację mniemanych zewnętrznych struktur zła czy tym bardziej stojących za nimi mniemanych winowajców.

Sprawą chrześcijaństwa - powiada - jest zło moralne, malum culpae, zło moralne tkwi tylko $\mathrm{w}$ jednostkach ludzkich, bo tylko jednostka jest odpowiedzialna. Złem jest zadawać innym cierpienie z nienawiści, to znaczy, że oprawca, który je zadaje, jest zły (przy czym na pewno jest takim zupełnie niezależnie od tego, w imię czego jest oprawcą i jak swoje rzemiosło usprawiedliwia); samo cierpienie natomiast nie jest złe w tym znaczeniu ${ }^{92}$.

Nie ma też sposobu, powiada Kołakowski, aby określić, jaki ustrój społeczny jest „sprawiedliwy”. W duchu koncepcji intrinsece malum Jana Pawła II polski filozof stwierdza przeto, że

nie potrafimy obliczyć jakie stosunki społeczne powodują więcej albo mniej powodów do nienawiści i chciwości; dla chrześcijaństwa chciwość jest tak samo zła u bogacza jak biedaka, nienawiść jest tak samo zła u ciemięzcy jak u uciemiężonego: na tym wszakże polega trudność bycia chrześcijaninem. Zemsta z tego punktu widzenia nie może przerwać łańcucha zła. [...] Zawsze jednak w chrześcijaństwie

88 Ibidem, s. 397.

${ }^{89}$ Ibidem, s. 398-399.

${ }^{90}$ F. Dostojewski, Biesy, s. 398. Te mimetyczną logikę przewidział polski wieszcz: Gęby za lud krzyczące sam lud w końcu znudzą,

I twarze lud bawiące na końcu lud znudzą.

Ręce za lud walczące sam lud poobcina.

Imion miłych ludowi lud pozapomina.

Wszystko przejdzie. Po huku, po szumie, po trudzie

Wezmą dziedzictwo cisi, ciemni, mali ludzie.

A. Mickiewicz, Gęby za lud krzyczace, [w:] idem, Wiersze, Warszawa 1975, s. 334.

91 „Tradycyjna nauka moralna Kościoła - pisze papież — mówi o czynach, które są » wewnętrznie złe« (intrinsece malum): są złe zawsze i same z siebie, to znaczy ze względu na swój przedmiot, a niezależnie od ewentualnych intencji osoby działającej i od okoliczności". Jan Paweł II, Veritatis splendor, Wrocław [b.d.w.], s. 123.

${ }^{92}$ L. Kołakowski, O tak zwanym kryzysie chrześcijaństwa, [w:] idem, Cywilizacja na tawie oskarżonych, s. 131 . 
pozostaje w mocy zasada, że zło w sensie właściwym i pierwotnym jest w nas [wyróżnienie — J.K.], nie zaś w stosunkach społecznych ${ }^{93}$.

Jak pisze dalej „orędziem Jezusa nie jest sprawiedliwy ustrój społeczny ani żaden ustrój społeczny w ogóle. Polecał on nam, byśmy niszczenie zła zaczynali od samych siebie, nie zaś od mordowania innych ludzi, których uważamy — słusznie czy niesłusznie — za złych"94.

Fatum rewolucji jest jednak to, że głosząc kres starego zła, zastępowała je nowym. Budując ,świecką eschatologię” i chcąc „cofnąć historię” (J. Baszkiewicz) do punktu zerowego musiała tak czy inaczej z historią się pojednać, tworząc nowe, często bardziej okrutne struktury zła w miejsce dawnych. Będąc próbą wyjścia ze świata historii, próbując unieważnić to, co przeszłe i projektując w jego miejsce nowy, absolutny i totalny ład, w końcu grzebała swoich promotorów; w rewolucji 1789 roku Robespierre'a, Dantona i innych, w rewolucji 1917 roku Trockiego i ikonę rewolucji - samego Lenina.

Tezę można potwierdzić na wielu przykładach rewolucji 1789 roku we Francji oraz 1917 roku w Rosji. Rewolucja francuska jak sowiecka, która miała charakter „skoku z królestwa konieczności do królestwa wolności”95 (co prawda nieudanego), były próbą negacji nie tylko historycznego i cywilizacyjnego gradualizmu, lecz także wszelkiego przedustawnego porządku, ale zamiast go znieść tylko potęgowała, wprowadzając nowy i własny rewolucyjny oparty na terrorze i strachu. Jedną przemoc zastępowała inną. Mimo ideowych deklaracji w praktyce okazywała się spotęgowaniem sił irracjonalnych, albowiem tylko w ten sposób mogła stać się jako revolutio, ale i zarazem jako re-volvere, co wydaje się potwierdzać tezę, że nie sposób pozbyć się zachowań mitycznych oraz mimetycznych, nie wpadając w następne.

\section{Oświecenie i rewolucja. „Nowa religia zamiast starej”}

Nawiążmy raz jeszcze do pracy Obecność mitu „Świadomość mityczna — pisze Kołakowski w tej książce — jest wszechobecna, chociaż najczęściej źle ujawniona"96. Mityczna perspektywa ustanawia odmienny poziom dyskursu i perspektywa ta nie może zostać w żaden sposób — wbrew wysiłkom partyjnych uczonych i partyjnych komisarzy — arbitralnym aktem unieważniona ani też odrzucona, gdyby nawet tak się stało oznaczałoby to koniec kultury i człowieka, którego komunizm w istocie, chciał przez praktyki unicestwienia przeszłości i instalacje Nowego Początku, czyli zarazem eksterminacje „mitologicznego” pnia kultury, sprawić. W tym znaczeniu, w takich pracach jak Obecność mitu Kołakowski pokazuje, że tak jak ,poszukiwanie pewności” w filozofii Husserla prowadziło do odkrycia nowych obszarów „niepewności"97 i wniosku, że nic nie jest tak pewne w filozofii, jak

\footnotetext{
93 Ibidem, s. 132.

94 Ibidem, s. 133.

95 Por. A. Walicki, Marksizm i skok do królestwa wolności. Dzieje komunistycznej utopii.

${ }^{96}$ L. Kołakowski, Obecność mitu, Wrocław 1994, s. 36. Por. także Rozumienie historyczne $i$ zrozumiałość wydarzenia historycznego, [w:] L. Kołakowski, Kultura i fetysze, Warszawa 1967.

${ }^{97}$ L. Kołakowski, Husserl i poszukiwanie pewności, Warszawa 1990, passim.
} 
właśnie niepewność i „mit”, a ucieczka od danego mitu prowadzi do następnego mitu, na przykład z jednego z ,mitów nauki” do następnego (na przykład „mit w pytaniu epistemologicznym”; „mit w świecie wartości”, „mit w logice”98), także rewolucja, wcale nieakcydentalnie, lecz ze swej istoty, pozostaje w kręgu mitycznych postaw i wyobrażeń i nigdy nie jest on na swoim terenie, lecz na terenie uprzednio mitycznie już zagospodarowanym. W eseju Odwet sacrum w kulturze świeckiej ${ }^{99}$ oraz w studiach na temat „diabła” Kołakowski, jak Talmon, Jung i Eliade, bierze niejako własny „odwet” na myśli naiwnie oświecicielskiej, pokazując, że zniknięcia sacrum zarówno w wymiarze świętym, jak i demonicznym (jako diabła) ze sfery społecznej ani nie da się zaprowadzić żadnym odgórnym dekretem, ani nie da sprawić za pomocą gilotyny ${ }^{100}$. Nie należy też tego sobie życzyć101.

Kołakowski dowodzi zarazem, że nie sposób pojąć istoty rewolucji oraz filozofii Oświecenia poza chrześcijaństwem. Jak Oświecenie, z którym jest ona powiązana, rodzi się ona na gruncie chrześcijaństwa i ustanawia w imię ideałów Kazania na Górze, które staje się podstawą świeckiego kodeksu praw człowieka i „świeckiej”, „odczarowanej” z elementów mitycznych i irracjonalnych, obywatelskiej religii. Skutki takiej preparacji są jednak dla cywilizacji chrześcijańskiej głęboko destruktywne, niszczycielskie ${ }^{102}$.

E. Cassirer podkreśla, że w Oświeceniu panuje „nastrój prawdziwie twórczy, bezwarunkowa ufność, że świat daje się kształtować i odnawiać. I takiej to odnowy wymaga się teraz i oczekuje od samej religii"103. Owszem, jak podkreśla, w Oświeceniu istnienie samej religii tłumaczy się niedostatkami ludzkiej wiedzy, lecz zarazem rozumie naturalne ludzkie pragnienia religijne i dlatego wdraża się budowę podstaw „religii naturalnej”104. Jak z kolei dobitnie stwierdza Talmon, „osiemnastowieczni philosophes nie mieli żadnej wątpliwości, że głoszą nową religię"105. Rewolucja, co doskonale rozeznawał także F. Dostojewski, zgodnie z wyjaśnieniem,

${ }^{98}$ L. Kołakowski, Obecność mitu, s. 15 n.

${ }^{99}$ L. Kołakowski, Odwet sacrum w kulturze świeckiej, [w:] idem, Cywilizacja na ławie oskarżonych, Warszawa 1990.

100 Por. A. Gniazdowski, Filozofia i gilotyna.

101 Kołakowski napisał: ,diabeł jest zapewne nieusuwalnym składnikiem sensownego świata. Wątpliwe jest także, czy powinniśmy sobie życzyć jego zniknięcia. Obecność jego utrzymuje w nas wrażliwość na zło; sprawia, że jesteśmy czujni i sceptyczni w obliczu optymistycznych nadziei na totalne zbawienie wszystkiego i na ostateczne pogodzenie wszystkich energii działajaccych w świecie" (L. Kołakowski, Diabet, [w:] idem, Czy diabeł może być zbawiony i 27 innych kazań, s. 190-193).

102 „Wszędzie odkrywamy ten sam podwójnie niszczycielski schemat: oświecenie wyłania się z chrześcijańskiego dziedzictwa rozważonego na nowo; by się utwierdzić, musi pokonać opór skostniałych krystalizacji tegoż dziedzictwa; utwierdzając się — w formie ideologicznej humanistycznej lub reakcyjnej — (to znaczy w formie reformacji) — oświecenie krok za krokiem oddala się od swojego źródła, by przybrać postać niechrześcijańską lub antychrześcijańską. W ostatecznych stadiach oświecenia obraca się przeciwko sobie: humanizm przeradza się w nihilizm moralny, niepewność poznawcza kończy się nihilizmem epistemologicznym, afirmacja osoby przechodzi niebywałą metamorfozę, z której wykluwa się jako teoria totalitarna" (L. Kołakowski, Szukanie barbarzyńcy. Złudzenia uniwersalizmu kulturalnego, [w:] idem, Cywilizacja na ławie oskarżonych, s. 34-35).

103 E. Cassirer, Filozofia Oświecenia, tłum. T. Zatorski, Warszawa 2010, s. 125.

104 Ibidem, s. 147 n.

105 J.L. Talmon, Źródła demokracji totalitarnej, s. 28. 
jakie kieruje do swego interlokutora jeden z głównych bohaterów powieści Biesy, a zarazem promotorów rewolucji w carskiej Rosji Piotr Wierchowieński: „Tu mój panie idzie nowa religia zamiast starej i dlatego zgłasza się tak dużo żołnierzy"106, zaczyna się od religii i na religii kończy.

Nie sposób zatem nie zauważyć, z czym zapewne zgodziłby się polski filozof, że w sferze pozornie zdesakralizowanych wyobrażeń rewolucyjnych odżywają z całą mocą w istocie odwieczne tematy i toposy religijne: nadzieja na powszechne „odnowienie" i całkowitą regenerację bytu, na mityczny powrót do nieskażonego historią, „Świętego czasu"107, owego przed-czasu, czasu in nullo tempore, powrotu do świata, jak piszą religioznawcy, do stanu w „czasie zerowym”, świata jaki był „na początku” i do jakiego, w wymiarze eschatologicznym, wszystko w rewolucyjnych ideologiach wydaje zmierzać (da się nawet odnaleźć w nich nadzieję na „odnowienie” człowieka — „nowy człowiek” św. Pawła).

Głodu sacrum i Absolutu, o czym przekonuje Kołakowski, nie da się zatem wykorzenić z żadnej sfery ludzkiej działalności, także ze sfery rewolucyjnej, co wydaje się potwierdzać pogląd M. Eliadego: „Absolutu nie można wykorzenić, można go tylko zdegradować”108. Mit można zastąpić tylko innym mitem. „Pożegnanie z Bogiem”, tak jak ,pożegnanie z diabłem” — ironizuje Kołakowski — nigdy nie jest ostateczne, a na tych, którzy odrzucili jednego (jedynego) Boga, spada „deszcz nowych bogów”. W miejsce odchodzących mitów i wiar rodzą się nowe wiary i nowe mity, „oświecone” namiastki i substytuty dawnych wiar i religii. „Smierć bogów”109 rodzi nowych „bogów". Po religii może przyjść tylko religia, pytaniem jest tylko jaka i dlatego

po stuleciach wzrostu oświecenia budzimy się nagle pośród zamętu umysłowego i moralnego; coraz większym lękiem napawa nas widok świata, który zaprzepaścił swoje dziedzictwo religijne i nasz lęk jest dobrze usprawiedliwiony. Miejsce rozwianych mitów zajmuje częściej nie oświecona racjonalność, lecz jej przerażające świeckie karykatury i substytuty ${ }^{110}$.

Owszem, jak dodaje, mając zapewne na myśli procesy desekularyzacji we współczesnym świecie i tak zwany postsekularyzm, ,powrót sacrum” stał się wręcz „,modnym tematem”111, lecz sami ,intelektualiści” mogą jedynie opisywać religijne fenomeny, lecz w żaden sposób nie mogą się przyczynić do ,żywotności mitu"112, do tego, aby dany mit był żywy.

Wynika to z samej istoty mitu. Mity to nie twory sztuczne. Mity żyją, obumierają oraz zmartwychwstają, tak jak odżył mit rewolucyjny w rewolucji francuskiej oraz bolszewickiej. Mitu nie można racjonalnie obalić, ponieważ mit nie jest prawdziwy ani fałszywy i żaden mit nie podlega dychotomii prawdy i fałszu. Słowem mit żyje,

106 F. Dostojewski, Biesy, s. 397.

107 M. Eliade, Sacrum $i$ profanum, s. 55 n.

108 J. Krasicki, „Śmierć Boga” i Nowa Europa, [w:] idem, Po „śmierci Boga”. Eseje eschatologiczne, Kraków 2011, s. 34.

${ }^{109}$ L. Kołakowski, Śmierć bogów, [w:] idem, Pochwała niekonsekwencji, t. 3, s. 158. Także: J. Krasicki, „Śmierć Boga" i Nowa Europa, s. 35.

${ }^{110}$ L. Kołakowski, Iluzje demitologizacji, [w:] idem, Cywilizacja na ławie oskarżonych, s. 235.

111 Ibidem.

112 Ibidem, s. 236. 
jest ,żywotny" lub nie ${ }^{113}$, a tezę tę potwierdza na przykład współczesny amerykański filozof A. McIntyre, wedle którego „mit jest żywy lub martwy, a nie prawdziwy lub fałszywy. Nie da się obalić mitu, gdyż w tym samym momencie, w którym dopuszcza się możliwość jego obalenia, nie traktuje się mitu jako mitu, lecz jako hipotezę lub historię"114. Mit nie jest zatem w ujęciu Kołakowskiego w żaden sposób synonimem nieprawdy, fikcji czy fałszu. Przeciwnie, oznacza „prawdę”, lecz innego nieempirycznego i niescjentystycznego rzędu, ponieważ daje odpowiedzi na pytania ostateczne i odpowiada na ostateczne pragnienia ${ }^{115}$. Te, którym dała wyraz rewolucja 1789 roku we Francji oraz rewolucja 1917 roku w Rosji.

\section{Zamiast zakończenia, czyli o tym, że „ostatnia” rewolucja jest zawsze ,przedostatnia" i że ,takiej rewolucji nie będzie nigdy"}

Hasło „bój to będzie ostatni”"116, jak przypomniał o tym jeden ze znakomitych warszawskich historyków idei, zapowiada ziemski eschaton. Jest ono jednak zarazem fatum rewolucji i śmiertelnym wyrokiem nad nią. Rewolucja oznacza koniec starego i początek nowego, ale że upragniony moment „zlania się" ideału z rzeczywistością, bytu i powinności nie następuje, ,zbawianiu” nie ma końca, zgodnie z uwagą J. Mirabeau, że po każdej rewolucji rodzi się potrzeba następnej, już tej „ostatniej”117. Ponieważ horyzont tożsamości ,ideału i rzeczywistości” ciągle się oddala, tak oto wbrew artykułom rewolucyjnej wiary „Królestwo Boże na ziemi” staje się pułapką, z której nie widać wyjścia; Heglowska „zła nieskończoność” nie chce stać się transcendentną Nieskończonością, ,koło historii” nie chce się zamknąć. Wprawdzie powiada się „bój to będzie ostatni”, wystarczy jeszcze jedna ta ostatnia

113 Ibidem, passim.

114 A. MacIntyre, Myth, [w:] Encyclopedia of Philosophy, P. Edwards (ed.), New York, t. 5, s. 434-437.

115 „W rozmowie z Nathanem Gardelsem zatytułowanej Man Does Not Live by Reason Alone (1991) Kołakowski przekonuje, że ludzkość nigdy nie wyzbędzie się potrzeby identyfikacji w kategoriach religijnych: kim jestem, skąd się wziąłem, gdzie jest moje miejsce, dlaczego mogę wybierać, jaki sens ma moje życie, jak stawić czoło śmierci? Religia jest kluczowym aspektem ludzkiej kultury. Potrzeb religijnych nie da się z kultury ekskomunikować za pomocą racjonalistycznych zaklęć. Nie samym rozumem człowiek żyje. Kołakowski pokazuje, że wiara w to, iż wszystkie problemy człowieka znajdą swoje techniczne rozwiązanie, jest nieszczęsnym dziedzictwem oświecenia, »także jego najlepszych przejawów: walki z nietolerancją, zadufaniem, przesądami czy bezkrytycznym kultem tradycji«. Istnieją rozległe obszary ludzkiego życia, wobec których człowiek pozostaje bezradny. Nasze przywiązanie do ideału nieograniczonego postępu paradoksalnie w niebezpieczny sposób ogranicza naszą moralną wrażliwość, co wiąże się ściśle ze zjawiskiem, które Kołakowski nazywa utratą świętości. Wraz z zanikiem świętości, która stawiała granice doskonałości, możliwej do osiągnięcia doczesnymi środkami, pojawia się jedno z najgroźniejszych złudzeń naszej cywilizacji: że ludzkie życie można poddać nieograniczonym przemianom, że społeczeństwo jest »zasadniczo « bytem nieskończenie plastycznym i że kwestionowanie tej plastyczności i tej doskonałości oznacza kwestionowanie całkowitej autonomii człowieka, a tym samym kwestionowanie wartości samego człowieka" (R. Kimball, Leszek Kołakowski i anatomia totalitaryzmu, tłum. T. Kunz, „Znak” 2010, nr 2 (657)).

116 A. Sikora, Postscriptum; w poszukiwaniu utraconego sensu, [w:] idem, Między wiecznościa a czasem, Kraków 2006, s. 119.

117 L. Kołakowski, Rewolucja jako piękna choroba, s. 189. 
rewolucja, ale okazuje, że zza niej wyłania się następna. Tak oto każda ostatnia rewolucja okazuje się przedostatnią.

Na zakończenie przytoczmy słowa polskiego filozofa, które mogą służyć za podsumowanie naszych rozważań, a mogłyby być zarazem memento każdej rewolucji.

Myśl, że istniejący świat jest tak doszczętnie zepsuty, że naprawić go niepodobna i że właśnie z tej racji świat, który po nim nastąpi, będzie pełnią doskonałości i ostatecznym wyzwoleniem — jest jedną z najbardziej monstrualnych aberracji ludzkiego umysłu; zdrowy rozsądek podpowiada bowiem, że im bardziej znieprawiony jest świat istniejący, tym dłuższa, tym trudniejsza i tym mniej pewna jest droga, która go dzieli od wyimaginowanego królestwa doskonałości. Aberracja ta nie jest wprawdzie wynalazkiem naszych czasów, przyznać wszelako trzeba, że jest ona znacznie mniej rażąca w myśleniu religijnym, które całość doczesnych wartości przeciwstawia sile łaski nadprzyrodzonej aniżeli w doktrynach świeckich, które zapewniają nas, że możemy własnym wysiłkiem z dna piekła przenieść się jednym skokiem na szczyty raju. Takiej rewolucji nie będzie nigdy ${ }^{118}$.

\section{Bibliografia}

Arendt H., O rewolucji, tłum. M. Godyń, Kraków 1991.

Baczko B., Jak wyjść z Terroru: Termidor a Rewolucja, tłum. W. Dłuski, Gdańsk 2005. Baczko B., Rewolucja. Władza, nadzieje, rozterki, tłum. W. Dłuski, Gdańsk 2010.

Bielik-Robson A., "Chce wierzyć”: Kołakowski między mitem a horror metaphysicus, („I Want to Believe”: Kotakowski Between Myth and Metaphysical Horror) https:// www.google.com $/$ url? sa $=$ t\&rct $=j \& q=\& e s r c=s \&$ source $=$ web\&cd $=1 \& c a d=r j a \& u a c$ $\mathrm{t}=8 \&$ ved=0ahUKEwiLl6KUmJ7bAhVGaFAKHViyBQQQFggnMAA\&url $=\mathrm{http} \% 3$ A\%2F\%2Fpublica.pl\%2Fteksty\%2Fbielik-robson-chce-wierzyc-kolakowski-miedzymitem-a-horror-metaphysicus-63512.html\&usg=AOvVaw3u5KQoV_YCvhsG-BuppiUj (dostęp: 13.03.2018).

Cassirer E., Filozofia Oświecenia, tłum. T. Zatorski, Warszawa 2010.

Chodubski A., O mimetycznym objaśnianiu rzeczywistości politycznej,http://cejsh. icm.edu.pl/cejsh/element/bwmeta1.element.desklight-fbb2784f-6fa1-4c07-ad13-36c7a81b4c71 (dostęp: 11.03.2019).

Chudoba W., Leszek Kołakowski. Kronika życia i twórczości, [w:] Protokół z zebrania Katedry Historii Filozofii z 26 marca 1953, AAN ANS 5/107.

Chudoba W., Leszek Kołakowski. Życie z historia w tle, „Res Publica Nowa” 230 [4] (2017).

Dostojewski F., Biesy, tłum. T. Zagórski, Warszawa 1977.

Duarte J.C., Problem zła w filozofii współczesnej, tłum. L. Balter, „Communio. Międzynarodowy Przegląd Teologiczny" 3, 1990, s. 32-43.

Eliade M., Sacrum $i$ profanum. O istocie religijności, tłum. R. Reszke, Warszawa 1996.

Europa i co z tego wynika (rozmowy w Castel Gandolfo), K. Michalski (red.), Warszawa 1990.

Flis M., Leszek Kołakowski — teoretyk kultury europejskiej, Kraków 1992.

Garewicz J., Kant i gilotyna, [w:] Dziedzictwo Kanta, J. Garewicz (red.), Warszawa 1976, s. 160-122.

Girard R., Sacrum i przemoc, tłum. M. i J. Plecińscy, Poznań 1994.

${ }^{118}$ L. Kołakowski, O duchu rewolucyjnym, s. 223-224. 
Gniazdowski A., Filozofia i gilotyna. Tradycjonalizm Josepha de Maistre'a jako hermeneutyka polityczna, Warszawa 1996.

Gontarczyk P., Kołakowski poza zasiegiem SB, http://www.teologiapolityczna.pl/piotr-gontarczyk-kolakowski-poza-zasiegiem-sb (dostęp: 11.03.2019).

Gromiec W., Kant a Rewolucja Francuska, „Archiwum Historii Filozofii i Myśli Społecznej" 5, 1979, s. 39-62.

Henrici P., Filozofowie a Grzech pierworodny, tłum. A. Parzonko, „Communio. Międzynarodowy Przegląd Teologiczny" 4, 1991, s. 76-86.

Jan Paweł II, Veritatis splendor, Wrocław [b.d.w.].

Kimball R., Leszek Kołakowski i anatomia totalitaryzmu, tłum. T. Kunz, „Znak” 2010, nr 2 (657), s. 38-51.

Kłoczowski J.A., Więcej niż mit. Leszka Kołakowskiego spory o religię, Kraków 1994, s. $52-67$.

Kłoczowski J.A., Sceptyk i mistyk, [w:] Obecność. Leszkowi Kołakowskiemu w 60-lecie urodzin, Londyn 1987, s. 52-67.

Kołakowski L., Diabet, [w:] idem, Czy diabeł może być zbawiony $i$ 27 innych kazań, Londyn 1984, s. 174-193.

Kołakowski L., Dwoje oczu Spinozy, [w:] idem, Pochwała niekonsekwencji. Pisma rozproszone sprzed roku 1968, t. 1, Londyn 2002, s. 145-161.

Kołakowski L., Husserl i poszukiwanie pewności, Warszawa 1990.

Kołakowski L., Iluzje demitologizacji, [w:] Cywilizacja na ławie oskarżonych, Warszawa 1990, s. 215-236.

Kołakowski L., Jeśli Boga nie ma... O Bogu, Diable, Grzechu i innych zmartwieniach tak zwanej filozofii religii, tłum. T. Baszniak, M. Panufnik, Kraków 1988.

Kołakowski L., Jezus ośmieszony, Esej apologetyczny i sceptyczny, tłum. D. Zańko, Kraków 2014.

Kołakowski L., Kapłan i błazen, [w:] idem, Pochwała niekonsekwencji. Pisma rozproszone sprzed roku 1968, t. 2, Londyn 2002.

Kołakowski L., Komunizm jako formacja kulturalna, [w:] idem, Cywilizacja na ławie oskarżonych, Warszawa 1990, s. 295-319.

Kołakowski L., Powstanie dialektyki, [w:] idem, Gtówne nurty marksizmu. Powstanie rozwój - rozkład, Londyn 1988, s. 15-70.

Kołakowski L., O duchu rewolucyjnym, [w:] idem, Czy diabeł może być zbawiony $i$ 27 innych kazań, Londyn 1984, s. 217-224.

Kołakowski L., O tak zwanym kryzysie chrześcijaństwa, [w:] idem, Cywilizacja na ławie oskarżonych, Warszawa 1990, s. 120-134.

Kołakowski L., Obecność mitu, Wrocław 1994.

Kołakowski L., Odwet sacrum w kulturze świeckiej, [w:] idem, Cywilizacja na ławie oskarzonych, Warszawa 1990, s. 135-154.

Kołakowski L., Rewolucja jako piękna choroba, [w:] idem, Cywilizacja na ławie oskarżonych, Warszawa 1990, s. 178-194.

Kołakowski L., Rozumienie historyczne i zrozumiałość wydarzenia historycznego, [w:] idem, Kultura i fetysze, Warszawa 1967, s. 221-238.

Kołakowski L., Szukanie barbarzyńcy. Złudzenia uniwersalizmu kulturalnego, [w:] idem, Cywilizacja na ławie oskarżonych, Warszawa 1990, s. 7-36. 
Kołakowski L., Śmierć bogów, [w:] idem, Pochwała niekonsekwencji, t. 2, Londyn 2002, s. $158-171$.

Krasicki J., Dwie krytyki gnozy, [w:] idem, Przeciw nicości. Eseje, Kraków 2002, s. 97-110.

Krasicki J., Eschatologia i mesjanizm. Studium światopogladu Mariana Zdziechowskiego, Wrocław 1994.

Krasicki J., „Śmierć Boga” i Nowa Europa, [w:] idem, Po „śmierci Boga”. Eseje eschatologiczne, Kraków 2011, s. 23-35.

Król M., Europa w obliczu końca, Warszawa 2012.

Król M., Leszek Wspaniały; https://www.tygodnikpowszechny.pl/leszek-wspanialy-134825 (dostęp: 11.03.2019).

MacIntyre A., Myth, [w:] Encyclopedia of Philosophy, P. Edwards (ed.), New York, t. 5.

Masłoń K., Leszek Kołakowski. Filozof rewizjonista; https://www.rp.pl/artykul/335966-Leszek-Kolakowski--Filozof-rewizjonista.html, (dostęp: 11.03.2019).

Mickiewicz A., Gęby za lud krzyczace, [w:] idem, Wiersze, Warszawa 1975.

O kryzysie (rozmowy w Castel Gandolfo), K. Michalski (red.), Warszawa 1990.

Otto R., Świętość. Elementy racjonale i irracjonalne w pojęciu bóstwa, tłum. B. Kupis, Wrocław 1993.

Ricoeur P., Symbolika zła, tłum. S. Cichowicz, M. Ochab, Warszawa 1986.

Rousseau J.J., Umowa społeczna, tłum. A. Peretiatkowicz, Kęty 2009.

Sikora A., Postscriptum; w poszukiwaniu utraconego sensu, [w:] idem, Między wiecznościa a czasem, Kraków 2006, s. 101-123.

Stecko J., Czy potrzebne jest nam sacrum? Diagnoza kultury w ujęciu Leszka Kołakowskiego, http://doi.prz.edu.pl/pl/pdf/einh/27 (dostęp: 11.03.2019).

Szacki J., Kontrrewolucyjne paradoksy, Warszawa 1965.

Talmon J.L., Źródła demokracji totalitarnej, tłum. A. Ehrlich, Kraków 2015.

Tischner J., Filozofia dramatu. Wprowadzenie, Kraków 1998.

Walicki A., Leszek Kołakowski $i$ warszawka szkoła historii idei, „Aletheia” 1, 1987, s. $121-132$.

Walicki A., Marksizm i skok do królestwa wolności. Dzieje komunistycznej utopii, Warszawa 1996.

Wildstein B., Kołakowski, czyli z powrotem do religii, https://teologiapolityczna.pl/ bronislaw-wildstein-kolakowski-czyli-z-powrotem-do-religii (dostęp: 11.03.2019).

Zdziechowski M., Chateaubriand i Napoleon, Wilno 1932.

Zdziechowski M., W obliczu końca, Wilno 1938.

Zdziechowski M., Widmo przyszłości, Wilno 1939.

Zdziechowski M., Wpływ rosyjskie na dusze polska, Kraków 1920.

Žižek S., Posłowie: Wybór Lenina, [w:] idem, Rewolucja u bram. Pisma wybrane z roku 1917 W.I. Lenin, tłum. S. Kurtyka, Kraków 2006. 